\title{
Year 2015 Benchmark Analysis on Realizing Performance and Emissions of Combustion Boilers
}

\author{
Jack Fuller $^{1}$, Yang Guo ${ }^{1}$ \\ ${ }^{1}$ College of Business and Economics, West Virginia University, Morgantown, WV, USA \\ Correspondence: Jack Fuller, College of Business and Economics, West Virginia University, Morgantown, WV, 26506, \\ USA.
}

Received: July 9, 2016 Accepted: July 30, 2017 Online Published: July 31, 2017

doi:10.11114/set.v4i1.2571 URL: https://doi.org/10.11114/set.v4i1.2571

\begin{abstract}
This current research effort will consider boiler conditions in 2015. The analysis was based on data gathered from a voluntary survey completed by plant owners and operators. The survey responses included the following: (1) boiler fuel sources, (2) efficiency performance, (3) environmental performance, (4) operations and maintenance activities, and (5) boiler availability. The analysis also included future concerns with respect to daily boiler operations from the responding plant operators and management.
\end{abstract}

Keywords: boiler, fuels, combustors, boiler operations, energy efficiency, environmental performance

\section{Introduction}

In the United States, combustion boilers are used either for power or for heating. Though the boiler industry began around 1876 (Bases, 2011), it has progressed rapidly. Many factors led to its speedy growth. One important factor was the growing need for electricity from other industries, urging the boilers to be much more efficient in power generation. This resulted in numerous breakthroughs in combustion technology over the years to satisfy the power needs and to protect the power supply stability. Today, the boiler industry has become mature but still contains potential issues. One of the current issues is in the reduction of boiler combustion emissions, either because they are hazardous, such as mercury and acid gases, or due to passive climate change. To reduce the negative impact from boilers on the environment, many regulations and laws have been implemented by setting limits on certain emissions that each boiler can emit in the air. For instance, The Environmental Protection Agency (EPA) has implemented the Boiler Maximum Achievable Control Technology (MACT) to control 188 hazardous air pollutants (HAPs) from boiler combustion (Center For Climate And Energy Solutions, 2017). The emission issue began the creation of boiler emission control devices and mechanisms as well as more environmentally friendly boiler combustion technologies. For example, the development of fluidized bed combustion (FBC) technology was started in the 1970s and has evolved as a primary way to lower the emissions of $\mathrm{SO}_{\mathrm{x}}$ and $\mathrm{NO}_{\mathrm{x}}$ down to an acceptable level without adding expensive gas cleaning measures (Rayaprolu, 2009). Before that, stoker firing technology had been used for more than 100 years. However, its popularity faded in the past decade mainly due to strict emission control and the competition from (FBC) technology. Besides boiler development and innovation, the healthy operation condition of each boiler in the industry is also crucial for the nation's power generation stability and efficiency. Government organizations, such as the American Society of Mechanical Engineers (ASME), who sets regulations for all types of boilers to standardize boiler design and manufacturing as well as boiler operations and maintenance (American Society of Mechanical Engineers, 2017), helped supervise the industry's daily health. Due to its importance and high environmental impact, the boiler industry deserves additional investigation. Therefore, the current research paper is going to serve as a diagnostic report of this industry in the United States.

\section{Methodology}

This current research effort will consider boiler conditions in year 2015. Previous research and government reports related to the boiler industry might be a potential source of data. However, the uniqueness of the topic and the certain time period discussed in this paper made it impossible to use the existing data. Therefore, a well-designed survey related to boiler operation performance and emission control performance was sent out as the main method to collect data in this paper. Plant owners and operators, who were members of the Council of Industrial Boiler Owners (CIBO), 
were invited to conduct this voluntary survey titled "Annual CIBO Boiler Operations and Performance Survey". The analysis was based on data gathered from this voluntary survey completed by plant owners and operators. Survey responses included the following: (1) boiler fuel sources, (2) efficiency performance, (3) environmental performance, (4) operations and maintenance activities, and (5) boiler availability. The current analysis will also include future concerns with respect to daily boiler operation from the responding plant operators and management.

\section{Research Analysis}

Previous studies concerning boiler conditions in each year have been conducted based on similar surveys since year 2000 (Fuller \& Robinson, 2015). A report from Energy and Environmental Analysis, Inc. provided a thorough investigation of the boiler industry based on the calendar year 2005 (Energy and Environmental Analysis, Inc., 2005). Later, the popularity of FBC boilers aroused attention of researchers. A five-year review paper was developed and published mainly focusing on the FBC boiler conditions from year 2007 to 2011 (Fuller \& Robinson, 2015). After this trending paper, another paper focused on year 2012 North American atmospheric fluidized bed industry and was ultimately published (Fuller \& Ayre, 2012). To update, the current research paper analyzes the condition of the boiler industry using the latest information acquired from the year 2015 survey. The boiler operation performance and emission control performance was investigated thoroughly in the following parts:

\subsection{Fuel Sources and Environmental Performance}

The electricity generating unit was used to measure the size of each plant in this research. As reported, $40 \%$ of the plants had less than or equal to $70 \mathrm{MW}$ net operation power and the remaining $60 \%$ were operated over $70 \mathrm{MW}$. Respondents were then asked about the types of fuels used in each plant. The primary fuel sources were coal $(20 \%$ of responding plants), gob ( $40 \%$ of responding plants), and natural gas ( $40 \%$ of responding plants). Sixty percent of the plants used secondary fuel sources: coal ( $40 \%$ of responding plants) and natural gas ( $20 \%$ of responding plants).

These responding plants included four different boiler technologies: $38 \%$ of the boilers at the responding plants were FBC boilers, $12 \%$ of the boilers at the responding plants were stoker-fired boilers, $44 \%$ were natural gas boilers, and $6 \%$ were cyclone boilers. The FBC boilers, stoker-fired boilers, and cyclone boilers all used coal or gob as their primary fuels and were typically industrial boilers (Eastern Research Group, Inc., 2001). The burning of coal, gob, or natural gas would emit pollutants. Three questions were asked to test the environmental performance of these boilers: (1) actual amount of $\mathrm{SO}_{2}$ emissions as a percentage of permit: (1) actual amount of $\mathrm{SO}_{2}$ emission as a percent of permit, (2) calcium/sulfur ratios, and (3) actual $\mathrm{NO}_{\mathrm{x}}$ as a percent of permit. The actual amount of $\mathrm{SO}_{2}$ emission as a percent of permit for each boiler showed an average of $88 \%$ for FBC boilers. The $\mathrm{Ca} / \mathrm{S}$ ratio, specifically for $\mathrm{FBC}$ boilers, had a mean of 3.6. The actual $\mathrm{NO}_{\mathrm{x}}$ as a percent of permit was $52 \%$ on average for $\mathrm{FBC}$ boilers and $56 \%$ on average for gas boilers. All the fly ash and bottom ash were fully used for beneficial purposes. For the control of other types of pollutants, one plant reported that they have improved their sorbent injection capacity for compliance to the promulgated Boiler MACT (for those with an operating power greater than $25 \mathrm{MW}$ ). The sorbent injection technology could help boilers control hydrochloric acid $(\mathrm{HCl})$ and filterable particulate matter (fPM) emissions, two of which were part of the controlled HAPs (U.S. Energy Information Administration, 2012).

\subsection{Efficiency Performance}

Boiler efficiency could be measured as a ratio of energy output divided by energy input, or the fuel usage (American Boiler Manufacturers Association, 2015). An industrial combustion boiler is estimated to have an average efficiency rate of $80 \%$ regardless of the fuel source (International Energy Agency, 2010). Comparing the industrial average number with the reported overall efficiency rate gathered (82\%), the reported boilers would seem to be in an average condition. To analyze the data more completely, the reported efficiency rate varied for different types of combustion technologies (see Figure 1). FBC boilers, having the most advanced technology, have the highest efficiency rate, about $85 \%$. Following that, the natural gas boilers reported an efficiency rate around $81 \%$. The stoker fired and the cyclone boilers, the two oldest technologies, averaged a $76 \%$ efficiency rate. 


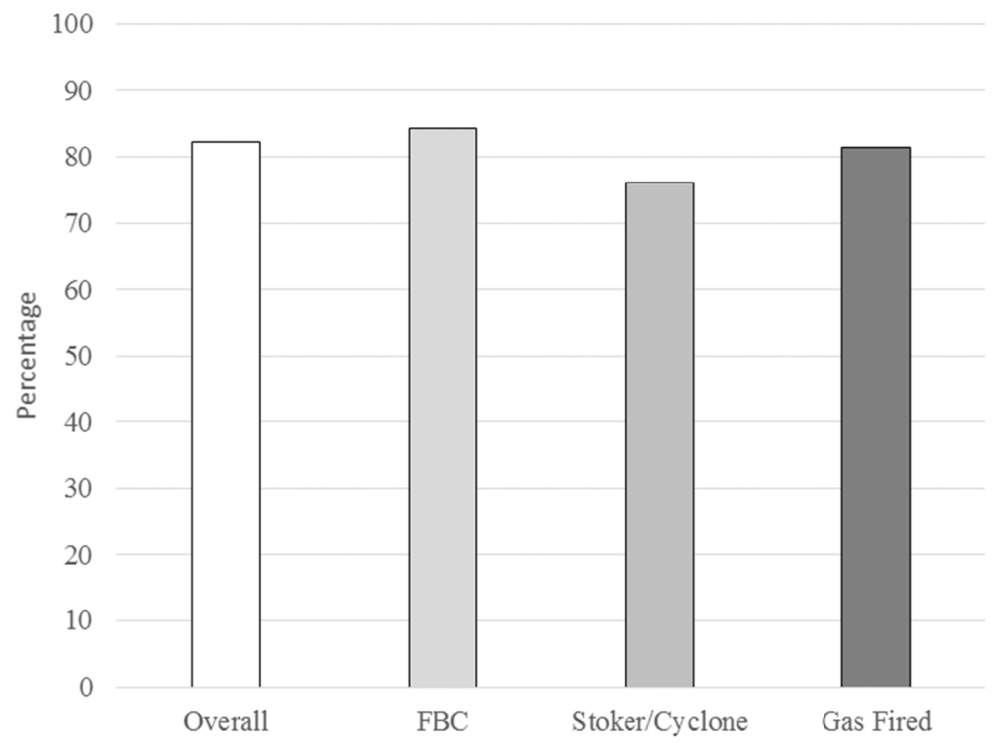

Figure 1. Boiler Efficiency Rating

\subsection{Operations and Maintenance Activities}

In this particular section, a set of questions was asked to measure the operation and maintenance performance of these plants (see in Table 1). The first part of the survey dealing with operations and maintenance (O\&M) concerned operations. From the survey results, one can see that an energy management program was implemented in almost all plants. However, only $60 \%$ of the plants required operators to have certification during work. The training for operators was provided by $100 \%$ of those plants, either in-house $(80 \%)$ or at external institutions $(20 \%)$. The external training expenditure was fully covered by those plants who could not provide in-house training for their operators. The next part of the survey concerned maintenance. Not surprisingly, all of the plants reported that they have a formal maintenance plan, while the length and the frequency of tune-ups varied significantly. Daily formal maintenance was implemented by $60 \%$ of the plants and monthly formal maintenance by $20 \%$ of the plants. The remaining $20 \%$ chose "Other" to not indicate a certain length of their formal maintenance plan. During the maintenance process, $40 \%$ of the plants had annual tune-ups and $20 \%$ had bi-yearly tune-ups. The other $40 \%$ of the plants performed tune-ups "as required".

Table 1. Operations and Maintenance Activities

\begin{tabular}{ll}
\hline 1 & Have energy management program? \\
2 & Is operator certification required? \\
3 & Is operator training available or required? \\
4 & Is operator training available in-house? \\
5 & Is external operator training company funded? \\
6 & Is external operator training individual funded? \\
7 & Does your plant have a formal maintenance plan? \\
8 & What is the length of your formal maintenance plan? \\
9 & How often are tune-ups required?
\end{tabular}

\subsection{Boiler Availability}

Boiler availability time should be divided into two categories: (1) availability hours with planned outages and (2) availability hours with forced outages. A forced outage is an unanticipated breakdown of a facility, lasting more than two days with unknown or emergency reasons. The planned outage (or scheduled outage) is designed for facility inspection, maintenance, etc. (U.S. NRC, 2017). Statistics showed that the annual availability related to scheduled outages was between $86 \%$ and $94 \%$ and the probability of a forced outage being very small (International Energy Agency, 2010), with only a $2.26 \%$ average of the overall reported forced outage hours for FBC boilers in 2015 (2.75\% for boilers burning coal and $1.6 \%$ for those burning gob).

The survey results contained two types of information related to the influence of fuel sources and combustion 
technologies on boiler availability. In the first type, the percent of time the boiler was available in different fuel sources was analyzed. The year 2015 witnessed a $92.8 \%$ overall average time boilers were available. The average percent of time available for boilers burning coal, gob, and natural gas was $92.5 \%$ for coal, $91.0 \%$ for gob and $93.7 \%$ for natural gas. In the second type, the analysis seemed to show reverse results. The average percent of forced outage hours in 2015 for different types of boilers is shown in Figure 2. The stoker/cyclone boilers experienced the highest average percentage of forced outage time (3.4\%). The FBC boilers and natural gas boilers reported an average of $1.4 \%$ and $0.8 \%$ forced outage time, respectively. The percent of outage time that was boiler related for different types of boilers was also examined (see Figure 3). Ninety percent of the forced outages and $97.5 \%$ of the planned outages on average were boiler related for FBC boilers and 100\% forced and planned outages on average were boiler related for natural gas boilers. Insufficient data was available for stoker/cyclone boilers to analyze them.

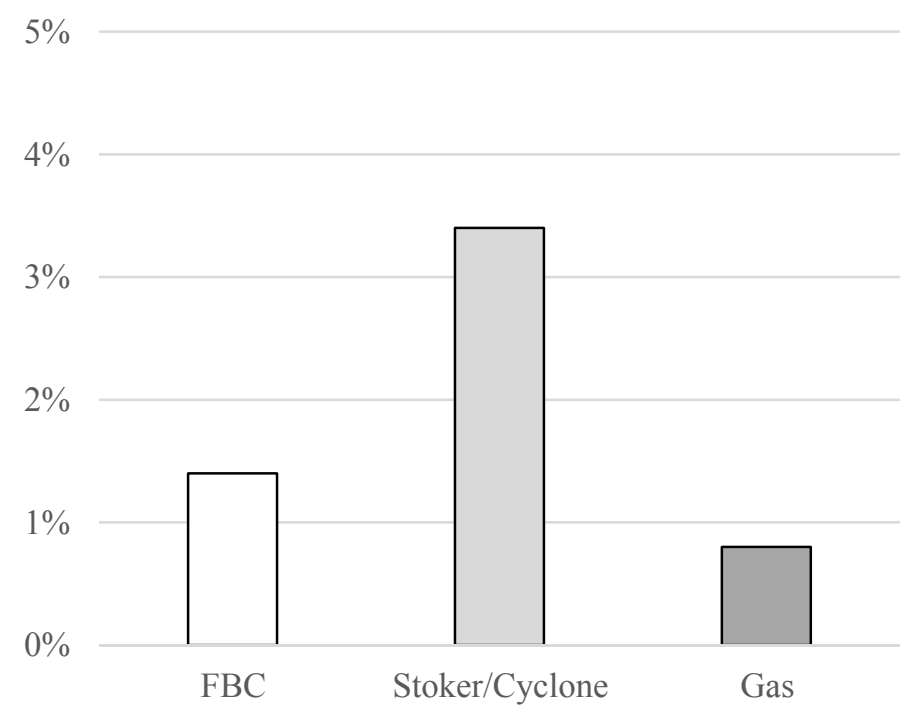

Figure 2. Percent Forced Outage Hours (by Boiler Type)

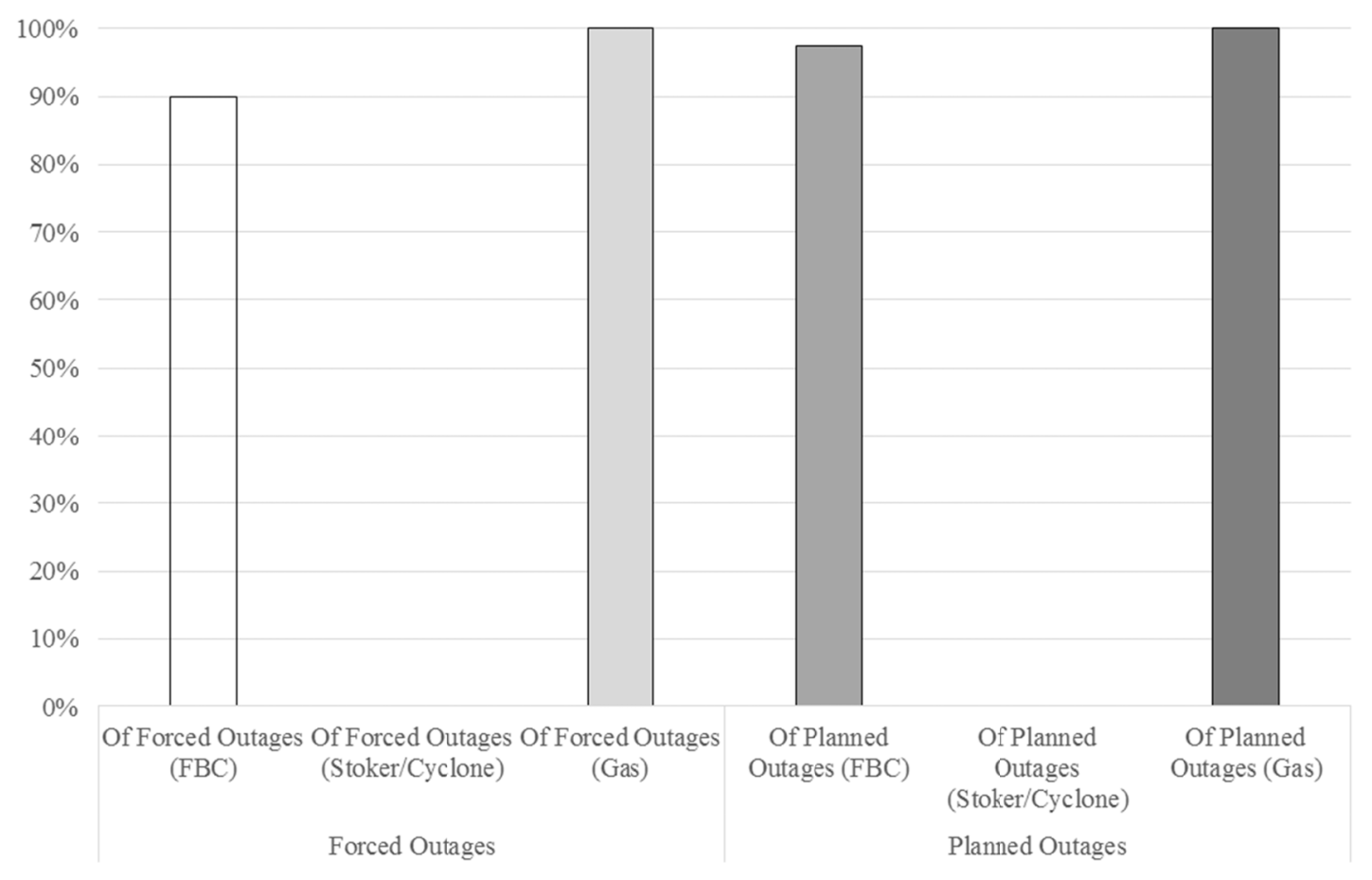

Figure 3. Percent of Outage Hours Boiler Related in 2015

Since forced outages occurred very rarely, a question was asked to see the detailed reasons behind this low probability situation. For FBC boilers (see Figure 4), "steam load" was the biggest cause of forced outages, about $45 \%$ on average. 
The second most significant cause was "backpass pressure parts", about $35 \%$ on average. The remaining came from "combustor pressure parts", "fuel handling", and "turbine \& electrical". For stoker/cyclone boilers (see Figure 5), "stokers" was the main reason for forced outages, about $40 \%$ on average. The other two important causes were "turbine \& electrical" and "cyclones". The survey also included questions for boilers with combination technologies (see Figure 6). These boilers combined more than one combustion technology, such as FBC and natural gas. The primary causes for the forced outages came from "turbine \& electric" and "combustor pressure parts". "fuel handling", "ash handling", and "backpass pressure parts", as indicated by the plant owners and operators.

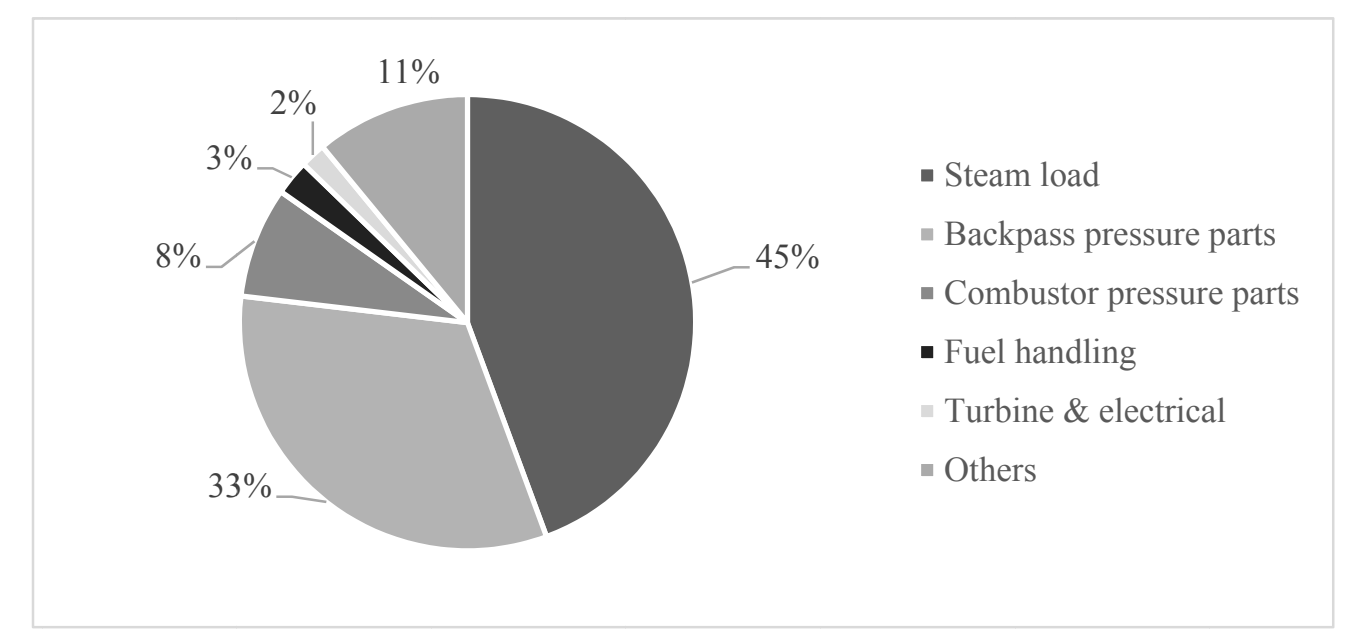

Figure 4. Forced Outage Causes in 2015 (at FBC units)

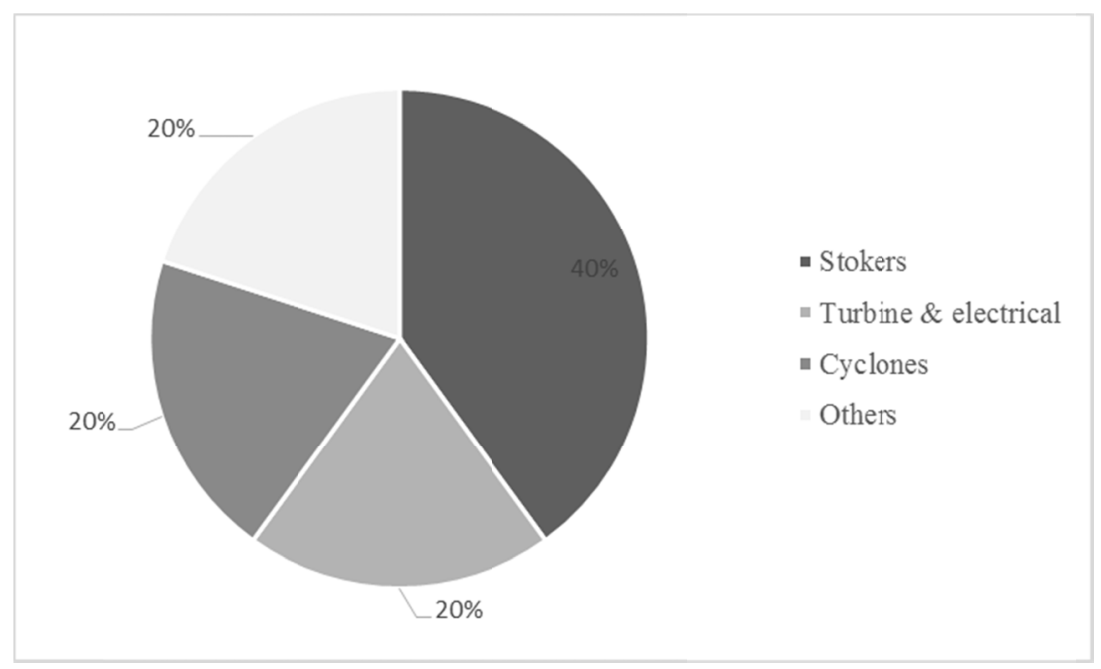

Figure 5. Forced Outage Causes in 2015 (at Stoker units) 


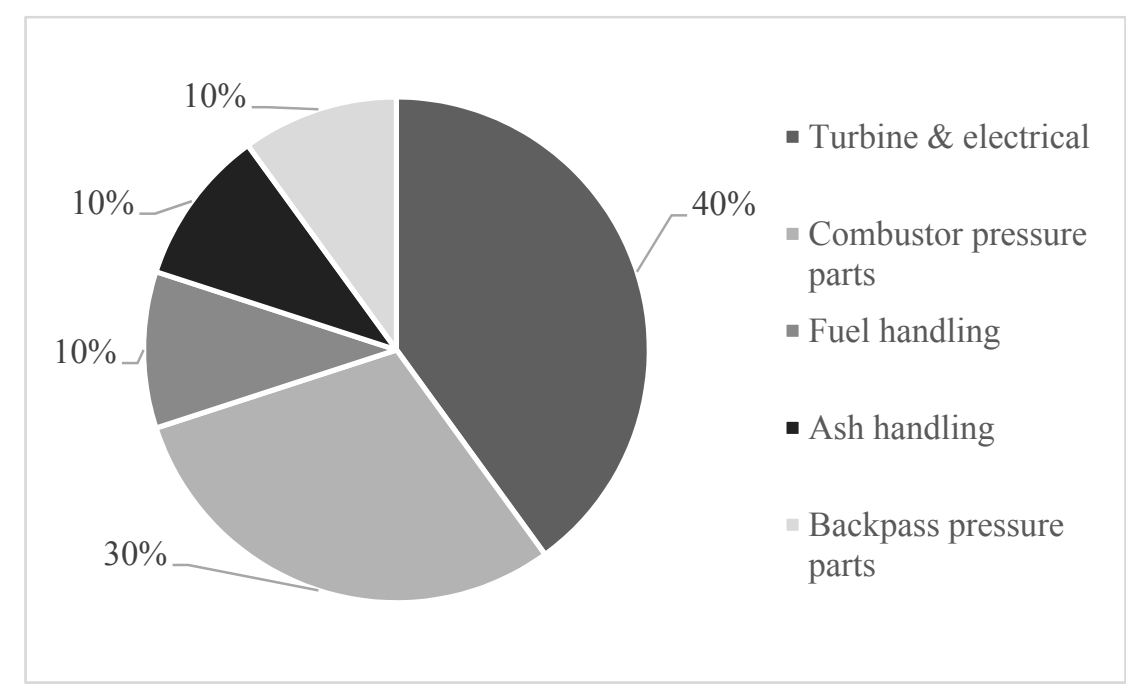

Figure 6. Forced Outage Causes in 2015 (at combination technology units)

\subsection{Concerns for Future Boiler Operations and Maintenance}

To facilitate better future boiler performance, the concerns for certain issues plant owners had for their future boiler operations and maintenance was pursued. They were asked to rate the type of issues (see Table 2) with a concern scale from " 1 " to " 10 " for the upcoming 2016 year of operation. The level of concerns increased as the scale number increased. Again, such questions were addressed for plants using different combustion technologies under three classifications: FBC plants, stoker plants, and combination technology plants. Detailed concern ratings for issues listed in Table 2 are shown in Figures 7 to 9. FBC plant owners expressed more concerns for those issues as compared with the other two types of plants. "Air heater" and "Boiler: Back pass" were rated above "8". "Loop seals", "Turbine/electrical", and "Ash cooling" were rated above "6". Stoker plants indicated a different picture. Though there appeared to be significant concerns with respect to "Expansion joints", the majority of the issues were rated low. The combination technology plants had no issues above a "7" level of concern. All types of plants shared a higher level of concern (above or equal to " 5 ") related to two issues: "Turbine/electrical" and "Ash cooling". 
Table 2. Type of Concerns for Future Boiler Operation and Management

\begin{tabular}{|c|c|c|}
\hline$\# 1$ & Issues related to & Fuel qaulity \\
\hline$\# 2$ & Issues related to & Fuel handling/crushing \\
\hline$\# 3$ & Issues related to & Fuel feeding \\
\hline$\# 4$ & Issues related to & Pressure parts \\
\hline$\# 5$ & Issues related to & Boiler: Combustion \\
\hline$\# 6$ & Issues related to & Boiler: Back pass \\
\hline \#7 & Issues related to & Refractory \\
\hline$\# 8$ & Issues related to & Ash cooling \\
\hline$\# 9$ & Issues related to & Stokers \\
\hline$\# 10$ & Issues related to & Emission Controls \\
\hline$\# 11$ & Issues related to & Burners \\
\hline \#12 & Issues related to & Cyclones \\
\hline$\# 13$ & Issues related to & Air heater \\
\hline$\# 14$ & Issues related to & Loop seats \\
\hline$\# 15$ & Issues related to & Expansion joints \\
\hline \#16 & Issues related to & Electrical controls \\
\hline$\# 17$ & Issues related to & Turbine/Electrical \\
\hline \#18 & Issues related to & Tube erosion \\
\hline \#19 & Issues related to & Combuster \\
\hline$\# 20$ & Issues related to & Pulverizers \\
\hline$\# 21$ & Issues related to & CEMs \\
\hline \#22 & Issues related to & Igniters \\
\hline$\# 23$ & Issues related to & Ash handling \\
\hline$\# 24$ & Issues related to & Bed ash \\
\hline$\# 25$ & Issues related to & Fly ash \\
\hline$\# 26$ & Issues related to & Ash regulations \\
\hline$\# 27$ & Issues related to & NSR definition changes \\
\hline \#28 & Issues related to & Seasonal emissions \\
\hline \#29 & Issues related to & CFBC cyclone \\
\hline \#30 & Issues related to & Cyclones (combustion) \\
\hline \#31 & Issues related to & Ash disposal \\
\hline \#32 & Issues related to & Operator error \\
\hline \#33 & Issues related to & Other \\
\hline
\end{tabular}




\section{0 \\ 9 \\ 8 \\ 7 \\ 6

$$
5
$$$$
4
$$$$
3
$$$$
2
$$ \\ 1 \\ 0}

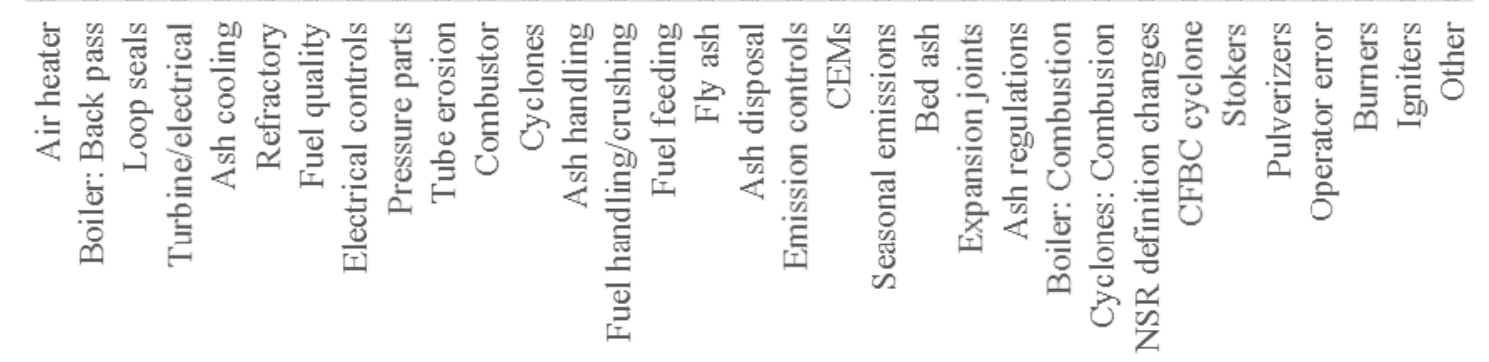

Figure 7. Boiler O/M Concerns for FBC Plants

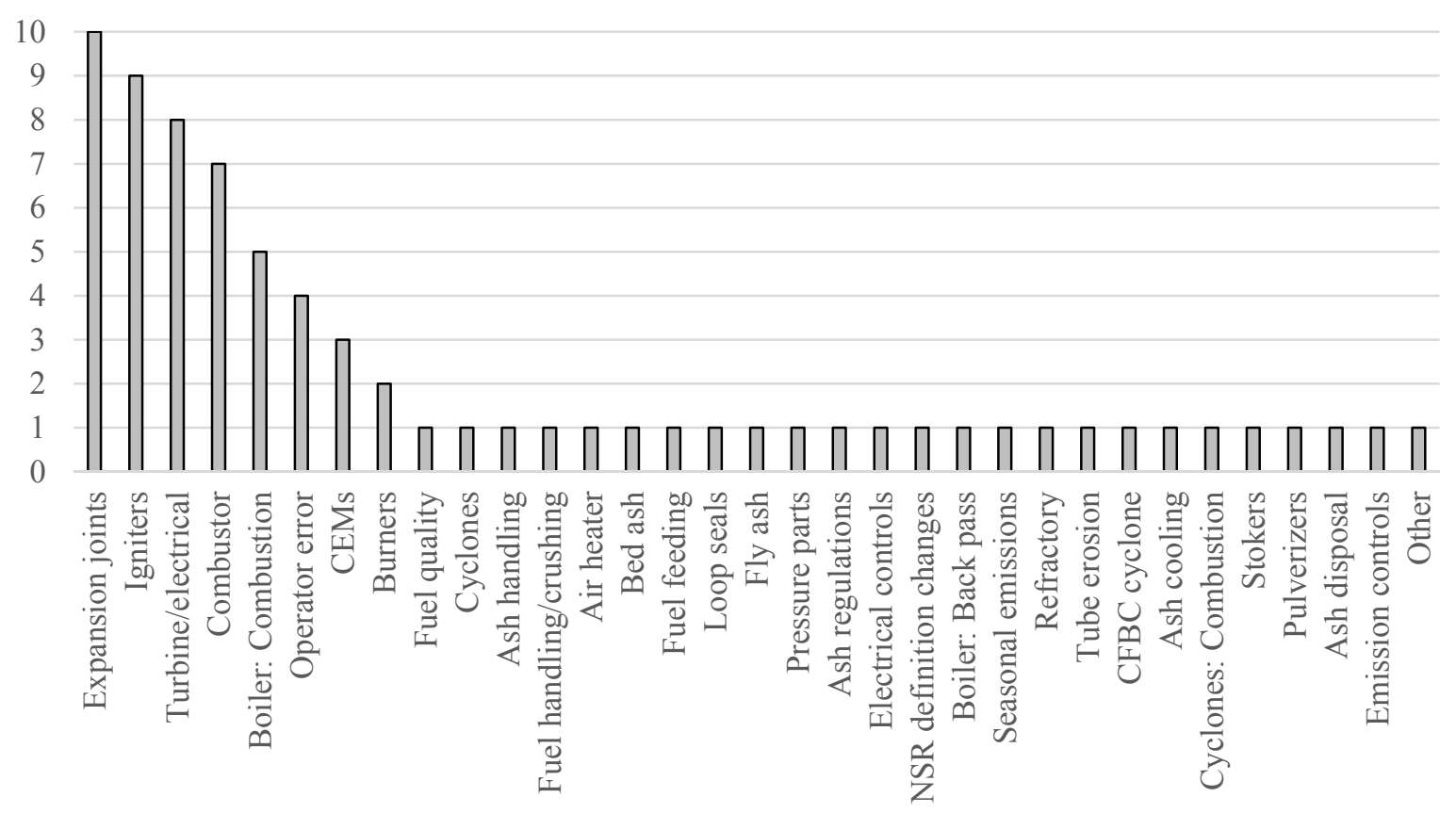

Figure 8. Boiler O/M Concerns for Stoker/Cyclone Plants 


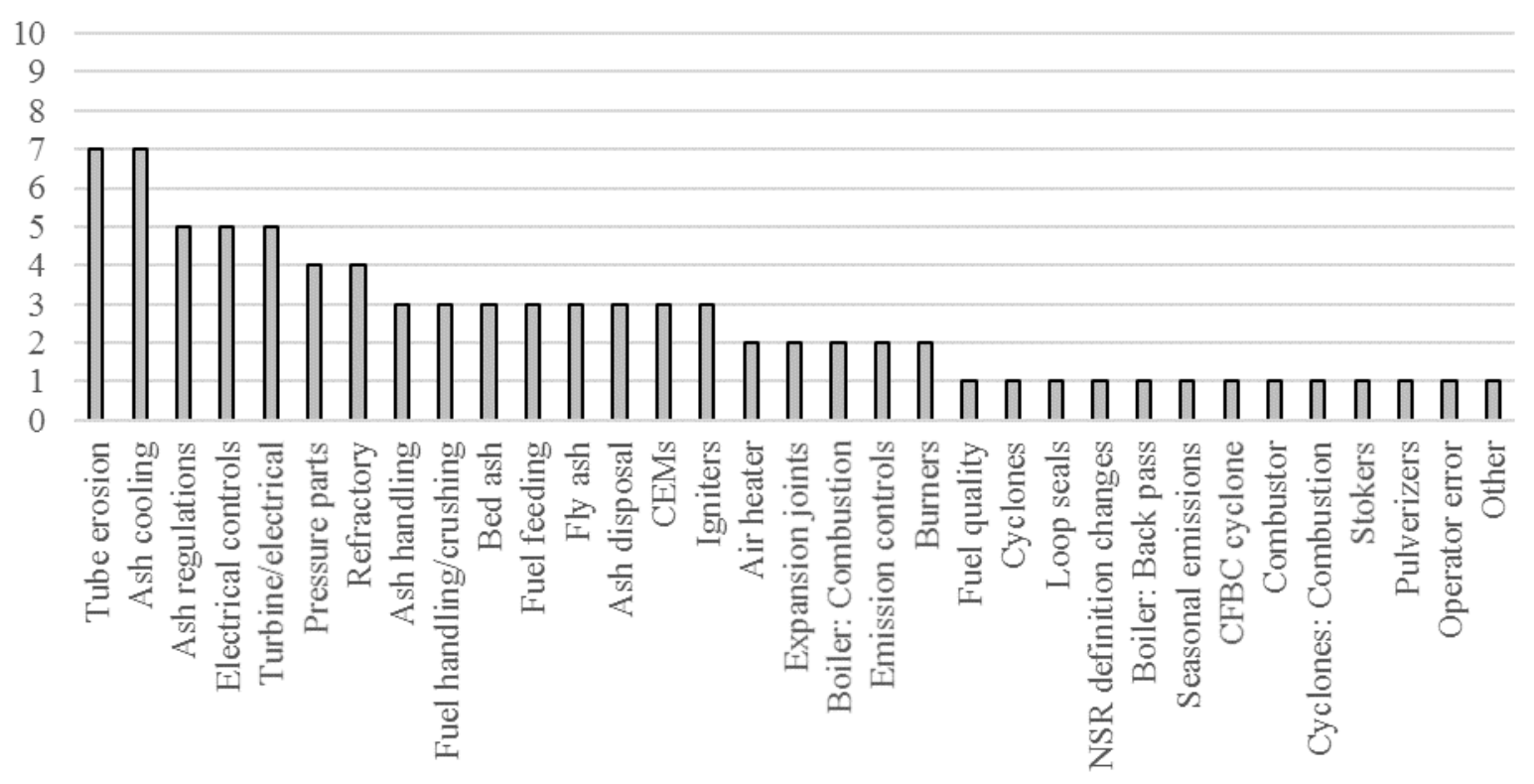

Figure 9. Boiler O/M Concerns for Combination Technology Plants

\section{Conclusion}

With stricter regulations implemented to limit the air pollutants in the boiler industry, the environmental benefits of using more costly technologies to reduce hazardous emissions and the operational profits of continually using older boiler technologies to save money had to be carefully balanced. The research indicated that most plants were utilizing regular boiler operation maintenance practices and good control of emissions. One plant had enhanced its combustion process to meet the Boiler MACT. Two primary factors were felt to influence boiler performance: fuel source and boiler technology. The analysis in this research mainly examined the differences on boiler performance from using different boiler technologies. FBC boilers exhibited better environmental performance and more stable availability. They were considered the most advanced type of boilers compared with their stoker/cyclone and gas counterparts. Though the analysis results portrayed the boiler industry as being in good condition, plant owners still had many concerns with respect to their future operations and maintenance. A safer, more stable, more environmentally friendly and less costly boiler technology is still needed to boost the industry's development.

\section{References}

American Boiler Manufacturers Association. (2015). Determining \& Testing Boiler Efficiency for Commercial/Institutional Packaged Boilers. American Boiler Manufacturers Association. Retrieved from http://www.abma.com/assets/docs/Tech_Resources/2015\%20-\%20commercial_boiler_efficiency.determine.test_20 08.pdf

American Society of Mechanical Engineers. (2017, June). Retrieved from https://www.asme.org/topics/standardscertification

Bases, G. (2011, May 1). The History of the Steam-Generating Boiler and Industry. Retrieved from insulation.org: https://insulation.org/io/articles/the-history-of-the-steam-generating-boiler-and-industry/

Center For Climate And Energy Solutions. (2017, February 14). What is the Boiler MACT Rule (National Emissions Standards for Hazardous Air Pollutants for Industrial, Commercial, and Institutional Boilers and Process Heaters)? Retrieved from Center For Climate And Energy Solutions: https://www.c2es.org/federal/executive/epa/boiler-mact

Eastern Research Group, Inc. (2001). Preferred And Alternative Methods For Estimating Air Emissions From Boilers.

Energy and Environmental Analysis, Inc. (2005). Characterization of the U.S. Industrial/Commercial Boiler Population.

Fuller, J., \& Ayre, L. (2012). Benchmarking the North American Atmospheric Fluidized Bed Industry. Energy Studies Review, 19(2), 32-42. https://doi.org/10.15173/esr.v19i2.541

Fuller, J., \& Robinson, M. (2015). Fluidized Bed Industry Benchmarking: A Five-Year Review. The Journal of Energy and Development, 41(1/2 (Autumn 2015 and Spring 2016)), 119-133. Retrieved from http://www.jstor.org/stable/90005934

International Energy Agency. (2010, May). Industrial Combustion Boilers. Retrieved from IEA ETSAP: 
https://iea-etsap.org/E-TechDS/PDF/I01-ind_boilers-GS-AD-gct.pdf

Rayaprolu, K. (2009). Boilers for Power and Process. CRC Press. https://doi.org/10.1201/EBK1420075366

U.S. Energy Information Administration. (2012, March 16). Dry sorbent injection may serve as a key pollution control technology at power plants. Retrieved from U.S. Energy Information Administration, Today In Energy: http://www.eia.gov/todayinenergy/detail.php?id=5430

United States Nuclear Regulatory Commission. (2017, April 10). Outage (forced). Retrieved from United States Nuclear Regulatory Commission: https://www.nrc.gov/reading-rm/basic-ref/glossary/outage-forced.html

\section{Copyrights}

Copyright for this article is retained by the author(s), with first publication rights granted to the journal.

This is an open-access article distributed under the terms and conditions of the Creative Commons Attribution license which permits unrestricted use, distribution, and reproduction in any medium, provided the original work is properly cited. 